\title{
The feasibility of ICT diffusion and use amongst rural women in South Africa
}

\author{
Alice Kwake' and Dennis N. Ocholla ${ }^{2}$ \\ Department of Library and Information Science \\ alice_kwake@hotmail.com,docholla@pan.uzulu.ac.za
}

and

\author{
Mathew O. Adigun ${ }^{3}$ \\ Department of Computer Science \\ University of Zululand, XI00I, KwaDlangezwa 3886, South Africa \\ madigun@pan.uzulu.ac.za
}

Received: $15^{\text {th }}$ November 2005

Accepted: $9^{\text {th }}$ April 2006

\begin{abstract}
This study explores whether ICT use is feasible in the rural areas of South Africa. Using the survey method, women aged 16-60 were sampled to include: Small-scale traders (58; 29.0\%); Housewives/homemakers (48; 24.0\%); Farm employees (25; 12.5\%); Domestic workers (18; 9.0\%); Educators/teachers (16; 8.0\%); Students (15; 7.5\%), Entrepreneurs managing large-scale enterprises (3; I.5\%); Clerical workers (9; 4.5\%); Community development workers (6; 3.0\%) and Preachers (2; 1.0\%). These 200 respondents formed the sampling size. Sampling data was obtained from Census household data of the magisterial districts of Umlalazi i.e. Eshowe, Amatikulu, Gigindlovu and Mtunzini. Using the snowball technique women respondents, directly and indirectly connected to each other, were identified, and consequently interviewed. The survey results indicate that access and exclusion are still predominant issues, as while a meager average of I I (5.5\%) respondents use modern technologies such as the computer/internet, more than half (I I5: $57.5 \%)$ of the respondents surveyed face problems ranging from affordability, to distance and time. Additionally, there is a marked correlation between the respondents' level of education, type of ICTs' accessed and information needs and purposes. It was observed that singularly, ICTs are insufficient for significant benefits to emerge.
\end{abstract}

\section{Introduction}

The purpose of this paper is to explore whether ICT use is feasible in the rural areas of South Africa. Although definitions as to what ICTs differ widely, they do bear some similarities. Ngenge, for example, (2003:I-2) comprehensively defines ICTs as technologies that enable the handling of information whilst facilitating different forms of communication between human actors, between human beings and electronic systems, and between electronic systems. He groups the technologies into four categories: - capturing technologies, storage technologies, processing technologies, communication technologies and display technologies. The European Commission 200I/ (2002:3) gives a fairly authoritative definition of ICTs. In this comprehensive definition, ICTs consist of "a wide range of services, applications and technologies, using various types of equipment and software, often running over telecommunications networks."The EC sums it up all adequately that ICTs are enabling and facilitating technologies. Individuals, community groups, business or government departments with access to affordable communications and computers can use them to save time and money and improve the quality of their work or home lives"( European Commission 200I/(2002:3).

The benefits of ICTs are difficult to gauge in many African countries, particularly in the wake of pressing problems such as poverty, hunger and disease. The United Nations Commission on Science and Technology for Development (UNCSTD) acknowledges the predicament that many African nations face, but warns of further isolation, if priority is not given to ICT strategies. For example, UNCSTD (in Marcelle, 200I:I) stresses that "ICTs do not offer a panacea for social and economic dislocation, and these may lead policy makers to give lower priority to the need to create effective national ICT strategies. However, on the basis of the evidence, it is apparent that the risks of failing to participate in the ICT revolution are enormous. Failure to give priority to ICT strategies that enable developing countries and countries in transition both to develop their national infrastructures and to join the Gll (Global Information Infrastructure) will exacerbate the gap between rich and poor. There is a growing need to evaluate the social and economic impacts of ICTs and to create opportunities for capacity building that will ensure their beneficial use and absorption within national economies and civil society."

It is therefore important to question whether ICTs can indeed alleviate poverty and improve human conditions, especially amongst rural African women. Needless to say, views on the role and usefulness of ICTs in African clevelopment

I. Alice Kwake is a PhD Student in the Department of Library and Information Science,University of Zululand

2. Dennis Ocholla is Professor and Head of the Department of Library and Information Science, University of Zululand

3. Mathew Adigun is Professor and Head of the Department of Computer Science, University of Zululand 
initiatives are diverse and occasionally contradicting. For instance, while Kenny (1995) argues that access to ICTS is dependent on education and income distribution, Moyo (1996) stresses the inevitability and pervasion of IT in all sectors of the economy. Some authors like Chowdhury in Adeya (2002:I) are of the opinion that "the poor cannot eat high-speed Internet", others like Barlow in Adeya (2002:I) maintain that "Africa should skip industrialism entirely and leap directly into the information era".

By the same token, Harris (2002:3) rightfully points out that, "there is still a widespread misunderstanding about how substantial benefits can be derived from ICTs ... as much of the difficulty arises because the development community has yet to get in touch with the IT community in a meaningful dialogue that would help both parties." According to Harris, the feasibility of ICTs in rural development is only possible when development strategies for information systems and technology are drawn from and harmonized with overall national development strategies. In his theory on Info mobilization, Harris (2004) advises that when considering the use of ICTs for development, it is essential to have a clear development strategy at the outset before the form of use of the ICTs is defined. The author admits that bottom-up, demand-driven development objectives are usually more preferable than top-down, supply-driven objectives, so that goals begin with an appreciation of the needs of development recipients, as they would themselves express them. In Harris's view, the application of ICTs in the absence of a development strategy that makes effective use of them will inevitably result in suboptimal results.

Nonetheless, viewpoints on the role of ICTs in rural development can be grouped into four major categories, namely: Political, Economic, Social and Technological (PEST).

Economic implications primarily focus on the importance of science and technology (Basson: 1996), Basson stresses the need for African governments to utilize science and technology and compete in commerce and industry. Rathgeber (200I) identifies poor infrastructure - including telecommunications infrastructure - and lack of skilled manpower as Africa's major challenges. For the purposes of comparison, Rathgeber observes that newly industrialized Asian countries took on this challenge and offered foreign investors not only skilled manpower, but also an excellent infrastructure. In 1995 for instance, ICTs accounted for more than 25\% of all exports from East Asian economies (Crede and Mansell in Rathbeger, 200I:3). According to the World Bank (1998/99:20), this capacity for ICT production has immensely contributed to East Asian economic growth. The World Bank further asserts that the "knowledge gap" in many developing countries is a contributory factor to poverty. According to this report, there is no better way to achieve the knowledge gap than through the use of ICTs. Due to their ability to decouple or separate information from its physical repository, ICTs are excellent channels of communication from one person to another. This view is supported by Pohjola in Bedi (1999:4) who argues that this decoupling characteristic is "revolutionary" as large bodies of information can be accessed by individuals regardless of time and space. Bedi (1999) adds that the use of ICT networks enables e-mail access to a varying number of individuals.

One of the most innovative breakthroughs of the 20th Century was the Internet, whose effects are changing how traditional technologies are used, and how wireless technologies are deployed. According to Marker, Wallace and Macnamara (2002: 14), the Internet dramatically reduces the costs of making information available to others and accessing global information and knowledge resources. The authors further add that Satellites and other advanced technologies make new things possible e.g. recent innovations in hand-held devices, in mobile telephony, and in satellite communications has led to new and cutting edge information and communication tools specifically relevant to the needs of the poor. In some developing countries, rural health workers are now using small hand-held devices to record health data from their clients

The social implications of ICTs are also highly regarded. Studies by Marker, Mcnamara and Wallace (200I:9-13) maintain a positive approach to the role of ICTs in development and affirm that ICTs do have an impact on the standards of living and on poverty alleviation at various community levels. Examples of ICTs access by the African rural poor to address their information needs are largely drawn from health, agricultural, community mobilization, and education and training

When looking at political implications, a narrative by Mudhai (2004:2-4) on the World Summit on Information Society (WSIS) held in Geneva, Switzerland, underscores the importance of ICTs in uniting African countries in development. Mudhai reflects on the latest developments initiated by African governments to leap into the "information age" and gives examples of achievements in Nigeria where there is an increase in fixed telephone lines from 300,000 to 720,000 and a rise in mobile phone subscribers from 500,000 to 2.5 million over the last two years. Other examples, given by Mudhai, are Egypt that stresses the importance of the E-Africa Connection project within NEPAD. Mozambique's and Rwanda's Heads of State reiterate that Africans have gone beyond the dilemma of choosing between ICTs and other development priorities. Mozambique has established a high-level multi-sector task force on ICTs, while Rwanda (a landlocked country) has "an ambitious ICT programme" poised to make it East Africa's technological hub, with broadband fiber-optic and 
wireless access to all schools, within three years. Equally encouraging is Botswana, which is investing in ICTs as an imperative industry with the proposed US\$300million East African Submarine Cable System (EASCS) optical fiber system. This cable system has docking points in Kenya, Tanzania, Uganda, Mozambique, Madagascar, Djibouti and South Africa. All these efforts are no doubt a step in the right direction for Africans, as ICTs can and will provide a new window for Africa to accelerate sustainable human development, which would inherently benefit rural women.

In this study, careful attention was given to women who reside in the rural areas of KZN. The word "rural" is intended to mean places with rural characteristics such as: low levels of service (e.g. transport, water and medical services), nonurban settlements (such as riparian villages) and high incidences of poverty (lkoja-Odongo 2002: 192). According to the Uthungulu District Municipality report (2003), the majority of the population within the Umlalazi Sub-Region is migrant, resulting in larger female numbers within the region. Further reports by the Uthungulu District Municipality (2003) indicate that the Umlalazi sub-region/municipality is mostly rural in nature, with a few urban settlements. The report asserts that the former KwaZulu districts are poorly developed with traditional, communal and tenure/ownership systems. The female population within the Umlalazi municipality constitutes $53.5 \%$, whilst the male population averages 46.5\% (UIDP 2002:4).

Marker, McNamara and Wallace (2001:9-14) argue that problems underlying rural development in most African countries are manifold, and include issues of access and exclusion, which are still quite significant. The authors further add that the Internet, is inclined towards more developed nations, well-to-do households and urban areas. Similarly, they are of the opinion that modern ICTs rely on physical infrastructure such as electricity and telecommunications that are poorly maintained and too costly to use. Besides the fact that ICTs are dependent on national policy, regulation for broadcasting licenses, and on the ensuing skills required (to use and manage ICTs), access to education and knowledge, particularly for girls and women, is still inadequate. Related problems and challenges have also been noted in studies by Ngimwa, Ocholla and Ojiambo (1997) on Kenya, Jiyane and Ocholla (2004) on South Africa, Ikoja - Odongo focusing on women entrepreneurs in Uganda (2002), and Mooko (2002) focusing on Botswana. All in all, given the multiple roles in society as mothers, wives and workers, women's voices are insufficiently heard. The International Technology Development Group [ITDG] (2005), expresses views that women rarely contribute to the policy debate about "poverty", as most of them are often illiterate, lack confidence and mobility.

In this paper, we will explore and attempt to answer the following questions: which ICT resources are used by rural women and why? What are the views on the use of and availability of ICTs in rural areas? How do ICTs enhance rural women's social welfare and quality of life? What problems do women experience when accessing and using ICTs? Which ICTs serve rural women's needs and in what areas?

\section{Research methodology}

Using the survey research method, an attempt was made to collect required data from a cross section of female inhabitants in the geographic region of the study in-order to determine the relationship between ICT resources accessed and used. The survey research design was found suitable, given the large number of respondents. However, the research design took into account aspects such as the purpose of the research, the accuracy required in the results, cost, time and labour involved. The survey instrument contained questions about the respondents' profile (race, age, education, and occupation), information needs and purposes, hindrances, use and availability of ICTs as well as areas in which ICTs serve women best.

The study primarily focused on rural women in the uMlalazi municipality. The uMlalazi municipality, situated in Uthungulu District in the Kwazulu Natal province, is mostly rural in nature with only a few urban settlements, and has more female inhabitants than male (Uthungulu Distict Municipality report 2003). Umlalazi is located on the north-eastern coast of the KwaZulu-Natal coastline. The area is underdeveloped although adjacent to the highly developed coastal corridor of KwaZulu-Natal [KZN] province. The study purposefully selected uMlalazi municipality for the investigation due to its rural location, having more women and a racial mix reflective of the South African population, and also bearing characteristics of rural communities outlined earlier (see Ikoja - Odongo, 2003). Uthungulu Distict has six local municipalities namely: Mbonambi; uMlathuze; Ntambanana; uMlalazi; Mthonjaneni and Nkandla (Uthungulu Distict Municipality report, 2004). According to this report, Uthungulu District has the third highest population in the province, after the Durban Metropolitan Council and the uMgungundlovu District. UMlalazi municipality has 26 wards [electoral areas represented by Councillors] (UIDP: 2002:4)

Through purposive sampling, seven wards were selected according to their individual population densities and racial mix. These wards included wards II, 12, 13, 15, 16, I8 and 25 of the Umlalazi Municipality. Accordingly, in order to avoid bias during selection, the aforementioned wards were placed in a box from which four wards were randomly drawn, namely: Eshowe, Amatikulu, Gigindlovu and Mtunzini. Statistically, the Eshowe ward has 3664 women, Amatikulu 3264, Gingindlovu 4060 and Mtunzini 7738. The sample size comprised of two hundred women. The selection of the sample 
size was informed by Gay's guidelines (1996:125) which state that: the larger the population size, the smaller the percentage of the population needed to get a representative sample; for smaller populations, $\mathrm{N}<100$, there is little point in sampling; if the population size is around 1500, 20\% should be sampled and beyond 5000, the population size is irrelevant and a sample size of 400 will be adequate. (As part of a comparative study involving two countries, i.e. Kenya and South Africa, a sample size of 400 was deemed suitable, given that the study population in both countries was beyond 5000. In this respect, this study on South Africa, takes into account a sample of 200). Additionally, using the snowball technique, women respondents connected to one another through direct and indirect linkages were identified and consequently interviewed. Analysis and interpretation of the research results is represented below.

\section{Results}

This section responds to the research objectives outlined in section I. Thus, besides the demographic profile of the respondents as outlined in section 3. I, section 3.2 responds to the first research question, "which ICT resources are used by rural women and why?", section 3.3 responds to an open ended question on the "uses and availability of ICTs in the rural areas of KZN?", section 3.4 responds to the question "how do ICTs enhance rural women's social welfare and quality of life?", and lastly, section 3.5 responds to "what problems do women experience when accessing and using ICTs"?

\subsection{Demographic profile of the respondents}

Respondents were asked questions that sought to ascertain personal information with regard to their field of occupation, educational attainment and age. The aim of these questions was to determine relationships between demographic characteristics, and the needs, purposes and uses of ICTs. The response rate to these questions was $100 \%$ as they were administered by one of the researchers. These questions were structured.

Of those interviewed, the highest number consisted of respondents between $31-40$ years $(66 ; 33.0 \%)$, followed by respondents in the age group of $13-20$ years $(41 ; 20.5 \%)$. Respondents between the ages of $41-50$ and those over 50 years were at third and fourth position with 35 (17.5\%) and 37 (18.5\%) respectively. The lowest age group consisted of $2 \mathrm{I}(10.5 \%)$ respondents between $2 \mathrm{I}-30$ years. With regard to levels of education, survey results indicated that the majority of respondents $(81 ; 40.5 \%)$ had acquired secondary education, while $62(31.0 \%)$ had primary education. However, only $34(17.0 \%)$ respondents had acquired tertiary-college/varsity education, with 23 (II.5\%) respondents reportedly having no schooling at all. Therefore an average of $72(35.8 \%)$ of the respondents have basic education. Regarding occupation, evidently, $58(29.0 \%)$ of the respondents are small-scale traders, followed by those who work as housewives/homemakers (48; $24.0 \%)$. Other categories are farm employees (25; $12.5 \%)$, domestic workers (18; $9.0 \%)$, educators/teachers $(16 ; 8.0 \%)$ and students $(15 ; 7.5 \%) .3(1.5 \%)$ respondents were entrepreneurs owning large-scale enterprises, consisting of a guesthouse, a sugar cane plantation and a fruit farm. Only $9(4.5 \%)$ respondents worked as clerical workers, and community development workers $(6 ; 3.0 \%)$. There were two preachers $(2 ; 1.0 \%)$.

\subsection{ICTs frequently used to access/receive educational, business/trade, health, agricultural and social welfare} information

The respondents were expected to respond to questions that sought to determine information requirements and purposes in various domains common to the rural environment. These domains included: education, health, business/ trade, agriculture and social-welfare. Subsequently, the respondents were expected to respond to questions that sought to determine the ICTs commonly used by them in their quest for information. This would mean that the respondents were either in possession of such technologies or had access to the technology in question, for instance, the internet, films or mobile cinemas.

Table I ICTs frequently used to access/receive educational, business/ trade, health, agricultural and social welfare information. $(n=200)$

\begin{tabular}{|c|c|c|c|c|c|c|c|c|c|c|c|}
\hline & \multicolumn{2}{|c|}{ Education } & \multicolumn{2}{|c|}{ Health } & \multicolumn{2}{|c|}{ Business } & \multicolumn{2}{|c|}{ Agriculture } & \multicolumn{2}{|c|}{ Social Welfare } & \multirow{2}{*}{$\frac{\mathrm{AV}}{\%}$} \\
\hline & $f$ & $\%$ & $\mathrm{~F}$ & $\%$ & $f$ & $\%$ & $f$ & $\%$ & $\mathrm{~F}$ & $\%$ & \\
\hline Radio & 160 & 80 & 162 & 81 & 110 & 55.0 & 142 & 71 & 160 & 80.0 & 73.4 \\
\hline Television & 82 & 41 & 88 & 44 & 68 & 34 & 70 & 35 & 86 & 43 & 39.4 \\
\hline Films & 32 & 16 & 40 & 20 & 9 & 18 & 22 & 26 & 32 & 16 & 18.2 \\
\hline Cell-phone & 25 & 13 & 35 & 18 & 25 & 13 & 28 & 14 & 33 & 17 & 15.0 \\
\hline Telephone & 25 & 13 & 8 & 4 & 10 & 5 & 23 & 12 & 33 & 17 & 10.2 \\
\hline Video & 30 & 15 & 12 & 6 & 12 & 6 & 2 & I & 22 & 11 & 7.8 \\
\hline Computer/Internet & 22 & 11 & 12 & 6 & 6 & 3 & 2 & 1 & 12 & 6 & 5.6 \\
\hline Mobile cinemas & 8 & 4 & 10 & 5 & 2 & 1 & 6 & 3 & 12 & 6 & 3.8 \\
\hline CD-ROM & 3 & 2 & 3 & 2 & 1 & I & - & - & - & - & 1.0 \\
\hline
\end{tabular}

SA Jnl Libs \& Info Sci 2006, 72(2) 
The survey took into account the possibility that an individual could use a combination of technologies while accessing or seeking information. Respondents were therefore at liberty to name all ICTs they used to access information, whether traditional or modern. By capturing these responses the survey was able to ascertain the ICTs that the respondents accessed and frequently used. It should be borne in mind that respondents also use other sources to obtain information, such as printed material, libraries, friends, neighbors etc. The response rate was $100 \%$ as questions were researcher administered.

In the field of Education, the information needs of respondents varied from student services/colleges (48.8\%), to course work/research topics (25\%), further studies (7.5\%) and funding sources (7.5\%), occupational information (5\%), social work (1.3\%) and business management (I.3\%) The reasons behind yielding educational information varied from personal welfare and better living standards, study assignments, counseling, further studies and job opportunities. The table above reveals that radio broadcasts are still highly prevalent as a source of information (160; $80 \%)$. The use of TV is relatively low $(82 ; 41 \%)$. While $32(16 \%)$ respondents also use film to access educational information, a similar number of respondents $25(13 \%)$ use the cell-phone and telephone. Videos are also used (30; $15 \%)$. In comparison to other sectors, the educational sector has the highest number of respondents using the computer/internet $(22 ; 11 \%)$. Only $8(4 \%)$ use mobile cinemas, and CD-ROMs (2\%) to access educational information.

The information needs of the respondents questioned with regard to health varied from respiratory illnesses e.g. TB and asthma $(21.3 \%)$ to HIV/AIDS (21.3\%), arthritis (10.6\%), terminal and chronicle diseases such as cancer $(6.3 \%)$, waterborne diseases $(6.3 \%)$, diet/nutrition $(6.3 \%)$, rheumatism (5\%), family planning $(5 \%)$, rabies (4\%), snake bites $(3.8 \%)$, sexually transmitted diseases $(3.8 \%)$ dentistry $(3.8 \%)$ and fits $(2.5 \%)$. The purposes of obtaining this information ranged from personal welfare to children's welfare and general awareness. The radio scored highly as a source of information as survey results revealed that $162(81 \%)$ use it to access information. The TV is equally important as 88 (44\%) respondents use it on occasion to source their health information. While $40(20 \%)$ respondents use film to access health information, there are more respondents who use the cell-phone $(35 ; 18 \%)$, than the telephone $(8 ; 4 \%)$. An insignificant number of respondents $(12 ; 6 \%)$ use the computer/internet and video $(12 ; 6 \%)$ for accessing health information. Only 10(5.0\%) use the mobile cinema, while 3(2\%) use the CD-ROM.

In the arena of business and trade, the occupations of the respondents varied from small-scale businesswomen in the informal sector, entrepreneurs, farmers, clerks, domestic workers, homemakers, teachers, retail/wholesalers and traditional healers. The areas in which respondents required information ranged from starting up a business (46.3\%), to cookery (13.8\%), Pricing/marketing (10\%), purchasing/supplies (10\%), stock management (7.1\%), financial management/book-keeping (6.3\%), horn - covering/tourism (2\%), hair and beauty salons (2.5\%) and poultry and animal husbandry (2\%). These needs seem to be closely related to the findings of a study by lkoja-Odongo (2002). The purposes behind obtaining this information ranged from skills enhancement, embroidery, stocking, financial help, financial management, business techniques, income-generation, seeking customers and family welfare.

Survey findings for business and trade reveal that while $110(55 \%)$ respondents use the radio alone for their information requirements, 68 (34\%) use the TV. The number of those who use film to obtain business information is 9 $(18 \%)$. Notably, though not necessarily unusual in modern times, there are more respondents who use the cell-phone $(25 ; 13 \%)$, than the telephone $(10 ; 5 \%)$. Videos are also accessed by $12(6 \%)$ respondents for business related needs. A negligible number of respondents $(6 ; 3 \%)$ use the computer/internet to obtain information. There were two respondents who used the mobile-cinema and one who used CD-ROMs.

The Agricultural information requirements of the respondents included farm inputs/new technology (28.8\%), crop type/diseases (22.5\%), soil types/fertility (18.8\%), livestock keeping ( $13.8 \%)$, herbicides/fencing ( $10.0 \%)$, and gardening/ crop management $(6.3 \%)$. The need for this information ranged from good harvests, enhancing animal fertility, preventing crop and animal diseases, improving sales, aesthetics and also spiritual offerings The majority of those interviewed (142; $71 \%)$ used the radio, while less than half of this number 70(35\%) used the TV. Cell-phones stood at 28 (14\%), while the telephone was used by $23(12 \%)$ respondents. Only $6(3 \%)$ respondents use the mobile cinema, while two (1\%) respondents use the computer/internet and video respectively.

The need to acquire social welfare information ranged from water resources and pit latrines $(42.5 \%)$ to music/ religious gatherings $(23.8 \%)$, travel/holidays (10\%), and community projects/women group activities $(8.8 \%)$, pension (8.8\%) and shopping/movies (6.3\%). Reasons for accessing this information ranged from leisure activities, entertainment, spiritual growth and relaxation and improved standards of living. Once again, the radio as a source of information scored high (160; 80\%). The TV (86; 43\%) was equally useful. Films (32; 16\%) were also used as a source of information. The use of the cell-phone and the telephone stood at $34(17 \%)$ and $32(16 \%)$ respectively. The video is used by $22(11 \%)$ respondents to source information, compared to $12(6 \%)$ respondents who use the computer/Internet for their information requirements. 
As a medium of information, the radio is evidently highly accessed, used by approximately $73 \%$ of rural women, particularly for education, health and social welfare needs. The TV plays an equally important role in sourcing information, as $39 \%$ of the respondents use it for their information requirements. The cell-phone has a clear advantage over the telephone, as $15 \%$ of the respondents' use it compared to $10.2 \%$ who use the telephone. Videos are used more by those in the field of education $(30 ; 15 \%)$ and social welfare $(22 ; 11 \%)$. Although the computer/internet scores a dismal average of only $5.6 \%$ amongst respondents, it is used more by those in the field of education (22; $11 \%)$.

\subsection{Use and availability of ICTs.}

In the table below, respondents were asked to give their personal responses to an open-ended question on the use and availability of ICTs in their community. The aim of this question was to capture varying opinions and attitudes on ICT use and availability in their community. Data was then analyzed using content analysis. The survey revealed that a large number $(57 ; 28.5 \%)$ felt that ICTs were not only unavailable and inaccessible to them, but also difficult to use. Similarly, 25 (I2.5\%) respondents felt that ICTs are costly and unaffordable. Coincidentally the number of those who found ICTs to be handy $(20 ; 10 \%)$ and those who felt that ICTs centers should be established near rural women $(20 ; 10 \%)$ were similar $9(9.5 .0 \%)$ respondents were of the opinion that ICTs were easily available and accessible, while $18(9.0 \%)$ felt that ICTs are affordable. A few respondents attuned to problems with infrastructure, such as lack of power $(13 ; 6.5 \%)$ and poor TV and radio networks (10;5.0\%).

Table 2 Comments on the use and availability of ICTs in the community. $N=200$

\begin{tabular}{lll}
\hline Comments & Frequency & Percent \\
\hline Unavailable, difficult to use & 57 & 28.5 \\
ICTs are costly \& unaffordable & 25 & 12.5 \\
ICTs are handy & 20 & 10.0 \\
Establish ICT centers near rural women & 20 & 10.0 \\
Easily available and accessible & 19 & 9.5 \\
ICTs are affordable & 18 & 9.0 \\
Lack of power & 13 & 6.5 \\
Great improvement in ICTS & 10 & 5.0 \\
Poor TV\& Radio networks & 10 & 5.0 \\
There's no trust in ICTs & 8 & 4.0 \\
\hline
\end{tabular}

3.4 How ICTs have enhanced the women's quality of life

Several arguments have been raised as to whether or not ICTs contribute to improving a society's quality of life. With this in mind, a structured question based on the likert scale was designed. Respondents were expected to answer the question based on "areas in which ICTs have served them best". In this question, the scale of 4 denoted a high and favorable response, i.e. "always", followed by scale 3 (i.e. "often"), scale 2 (i.e. "Sometimes") scale I (i.e. "never") and a "not applicable" scale. By calculating the average for each area listed, the study was able to arrive at conclusive remarks.

Table 3 How ICTs have enhanced the women's quality of life $(\mathrm{N}=200)$

\begin{tabular}{|c|c|c|c|c|c|c|}
\hline & $\begin{array}{c}\text { (4) } \\
\text { Always }\end{array}$ & $\begin{array}{c}\text { (3) } \\
\text { Often }\end{array}$ & $\begin{array}{c}(2) \\
\text { Sometimes }\end{array}$ & $\begin{array}{c}\text { (I) } \\
\text { Never }\end{array}$ & $n / a$ & $\begin{array}{c}A v=\% \\
(4+3+2)\end{array}$ \\
\hline To listen to news & 157 & 12 & 14 & 12 & 5 & 91.5 \\
\hline To keep in touch with family and friends & 160 & 2 & 8 & 24 & 6 & 85 \\
\hline Entertainment & 88 & 35 & 20 & 47 & 10 & 71.5 \\
\hline To fax documents & 41 & 17 & 30 & 90 & 22 & 44 \\
\hline Data processing & 38 & 5 & 15 & 115 & 27 & 29 \\
\hline For research purposes & 20 & 15 & 18 & 130 & 17 & 26.5 \\
\hline E-commerce/Trade & 10 & 13 & 18 & 118 & 41 & 20.5 \\
\hline Contact business support agencies & 25 & 3 & 10 & 138 & 24 & 19 \\
\hline Internet and related services & 20 & 6 & 12 & 160 & 2 & 19 \\
\hline For distance education & 28 & 5 & 6 & 134 & 27 & 16.5 \\
\hline
\end{tabular}

Evidently, ICTs enable most women to keep abreast of current affairs. Many rural women underscored the role ICTs play in daily news broadcasts. Most (9I.5\%) respondents felt that ICTs, particularly the radio and TV, helped them socially 
enrich their lives. This was followed closely by the need to keep in touch with family and friends (81\%). To most respondents, the mobile phone was particularly useful in this regard. Under entertainment, the respondents listed the ability to listen to music and other entertaining programs as important. With the help of ICTs, this service accounted for (7I.5\%). Interestingly, the use of the fax machine (44\%) also stood out as an important role played by ICTs.

3.5 Hindrances to the use and availability of ICTs

In the table below, respondents were asked questions relating to ICT hindrances. Using a close-ended questionnaire, appropriate multiple answers were selected. Notably, I 13(56.5\%) respondents felt that ICT services were unaffordable, with another $93(41.5 \%)$ stating that ICTs were too far removed from them. Other inhibitors were time (93; $46.5 \%)$, computer illiteracy $(42 ; 21.0 \%)$, poor roads $(25 ; 12.5 \%)$ and cultural taboos (15; 7.5\%). The above figures clearly illustrate that problems of access and exclusion for women in rural areas are evident, as an average of 96 (48\%) respondents faced problems ranging from affordability to distance and time.

Table 4 Hindrances on the use and availability of ICTs in the rural areas of KZN $(N=200)$

\begin{tabular}{lcc}
\hline Impeding factors & Frequency & Percent \\
\hline ICT services are unaffordable & $1 / 3$ & 56.5 \\
Time & 93 & 46.5 \\
ICT services are far away & 82 & 41.0 \\
Computer illiteracy & 42 & 21.0 \\
Roads are poor & 25 & 12.5 \\
Cultural Taboos & 15 & 7.5 \\
\hline
\end{tabular}

\section{Discussion}

Which ICT resources are used by rural women and why?

Needless to say, the use of old technologies, such as radio and TV, are high in all sectors. For instance, the use of the radio alone scored an average of $73.4 \%$, while the use of TV averaged $39.2 \%$ amongst respondents. Notably, these two ICTs are highly prevalent, which is in stark contrast to modern technologies such as the internet and video.

Compared to the telephone (10.2\%), the mobile phone scored reasonably well against "new" technologies currently on the market (15.0\%). Evidently, the versatility of the cell-phone transcends poverty and geographical boundaries. Authors such as Batchelor, Scott and Taylor (2005:9) underscore the importance of the mobile phone saying that villages are willing to pay up to $\$ I$ per minute to make essential calls. This is because cellular technology gives access to crop prices, market information and currency rates. The EC (200I/2002) also adds that, telecomm demands are highly price elastic and that the usage level of mobile phones amongst all sections of the population, including the poor, increase very rapidly once prices are brought down.

What uses and how available are ICTs in the rural areas of KZN?

The survey portrayed that an average of $54(27 \%)$ respondents felt that ICTs were too far, too costly or unavailable for their use. On this note, Harris (2004:35) underpins the fact that effective applications of ICTs must comprise a technological and physical/information infrastructure. According to this author even when such infrastructure is in place, difficulties arise when it is too costly to use, too far to access and also poorly maintained.

Suffice it to say that although the idea of tele-centres did crop up as a viable solution amongst 20 (10\%) of the respondents, careful attention must be given not only to the development activities envisaged, but also to the management, relevance of the information repositories and the telecommunication infrastructure of the area. For instance, lessons learnt from a study carried out by Parkinson (2005: 40-4I) in Bhamshela (about two hours drive from Durban), indicated a need for locally relevant services for example, voice telephony and job related computer skills. Snyman and Snyman (2003:10) also argue that although MPCCs form the back bone of development communication and the dissemination of information to needy communities.... they lack effective management, well-maintained and working equipment, relevant information as well as the much advocated access to the internet gateway". Similarly, Maepa and Mphalele (2003:3) attest to the fact that telecentres should be established within "needs of rural communities" in areas such as education, health, agriculture, business development and governance, amongst others. In this case, the effectiveness and efficiency of ICT projects in rural development would depend on how much they are embedded within such development issues. A good example of such an effort can be seen in programs such as SchoolNet South Africa, which is a GSA initiative devoted to expanding Internet use in South African Schools. SchoolNet SA is one of 25 SchoolNets in Africa and is supported by GSA's Department of Education. It also receives support from private sector companies such as Microsoft, Cisco, Nortek, Sun and \#Com. Activities conducted by this initiative include Internet 
connectivity, human resource development advocacy and marketing (AED, undated; Holcroft: 2005). In this way, ICTs can be "best deployed to improve processes that are already working reasonably well" (Harris, 2004).

How do ICTs enhance rural women's social welfare and quality of life?

An average of $91.5 \%$ of the respondents indicated that ICTs [particularly the radio and TV] played a major role in helping women keep abreast with current events within and beyond the South African borders. This ability to enhance the quality of life for rural women is supported by the fact that the radio is free and does not require a telephone line or literacy to access it. The radio also has the flexibility to disseminate information in various languages and is a platform for social debate amongst rural and urban communities. (Ranchod, 2000); (llboudo, 2003:206 in Girard 2003). The mobile phone was also highly rated by the respondents as $80 \%$ of the women felt that the mobile phone is a handy tool when it comes to communicating with family and friends and during emergencies. This view is also shared by Vodafone/DFID (2005:44), who conducted a recent survey in South Africa and Tanzania. According to this report, social impacts such as improved relationships with family and friends were major advantages of the mobile phone.

What problems do women experience when accessing and using ICTs?

The aforementioned study confirmed that problems of access and exclusion are still readily apparent, especially with regard to the use of computers and the internet, which accounted for only $6(5.6 \%)$ of the respondents. These views are confirmed by Marker, Wallace and McNamara (2002:12) who argue that poor infrastructure, unreliability of ICTs and high costs are major hindrances to ICT development in developing countries. It has also been noted that problems of access and exclusion in rural areas are also compounded by lack of relevance to local conditions. For instance, authors such as Ballantyne, Labelle, and Rudgard (2000:2), argue that the use of the Internet is constrained in developing countries by the low provision of appropriate content, both in terms of language and subject matter. By the same token, Bridges.org (200I), denote that "real access" to technology is one of the key elements necessary for integrating technology into society. This organization further describes access to mean "physical access". In other words, is the technology in question available and physically accessible? Additionally, is the technology affordable? The survey results indicate that a large number of rural women $(96 ; 48 \%$ of respondents) face problems ranging from affordability, availability, distance and time.

As previously mentioned, most rural women are still educationally disadvantaged as survey results illustrate that, $31 \%$ [of respondents] had obtained primary education alone. Additionally, $11.5 \%$ of the respondents that were indicated as having no schooling were from the black community (see section I). This is over and above the fact that $42(21 \%)$ of the respondents identified computer illiteracy as an impeding factor to accessing ICTs. Other impeding factors from the respondents, though insignificant, revealed a general feeling of apathy, and include lack of electrical power (13; 6.5\%), untrustworthiness $(8 ; 4.0 \%)$, and poor TV and radio networks (10; $5.0 \%)$.

From the above figures, the following deductions can therefore be made. In order to create a demand-driven ICT consumer community in the rural areas, the hindrances to accessibility must be significantly reduced either before or during the provision of the technology. This necessitates training and skill enhancement initiatives amongst other participatory development programs such as focus group discussions, direct interviews and workshops (Bessette, 2004; Harris 2004:39). In support of such views, authors such as Ballantyne, Labelle and Rudgard (2000) also argue that the use of ICTs is limited by lack of awareness and skills, training and a shortage of capital resources required to purchase and maintain equipment. As an added initiative, the development of professionals and teachers as viable intermediaries for bridging the digital divide for the low-literate or illiterate youth in school education programs in the rural areas, can also be used (Wagner, 2005).

Be that as it may, some of the aforementioned setbacks to the feasibility of ICTs in rural areas should not be seen as reasons for neglecting the prioritization of ICT projects in these areas. There are several meritorious ICT interventions being used today that could serve as learning platforms for African countries. A good example is the Bangladesh mobile help line for women, better known as Pallitathya. According to The Association for Progressive Communications (APC, 2005), this enterprising group of rural women deploys women in the community as "mobile operator ladies". These women move from door to door to enable the women, mostly housewives, to ask questions related to livelihood, agriculture, health and legal rights via the mobile phone. The "help-desk" operator comprises not only an information database, but resource persons from government, NGO's, health groups and human rights organizations. Notably, the activities of this group have been highly acclaimed by the Gender and Information Communication Technology (GICT):they won Ist prize beating 39 other entries in a recent 2005 ICT contest.

Another idea of introducing telecommunication services into a rural community whilst offering them an income generating viability is the example of Grameen Telecom. Grameen Telecom (2005) is an NGO set up by Professor Muhammed Yunus who had a vision of providing telecommunication services to the 100 million rural inhabitants in the 
68,000 villages in Bangladesh. This is by no means a small number of villagers! The concept of this organization combines bank experience, in this case, Grameen Bank, with village based micro-enterprises, the latest digital wireless technology, and Public Call Offices (PCOs) and privately operated phone centers. Grameen Bank provides a lease-financing program to a village phone operator, who then becomes the owner of the phone. This village phone operator can then provide outgoing and incoming services to people in adjoining areas and also collect daily call charges. Grameen Bank provides organizational and infrastructural support to Grameen Telecom whilst also collecting phone bills and other dues. This idea has proven successful as the project benefits all parties concerned whilst catering for the needs of the communities.

\section{Conclusions}

The fact that information is power and that women constitute more than half of the population in most African countries, necessitates the need to prioritize actions needed to help women have access to information (Solange and Momo, 2005:6). According to these authors, these actions require the need to first always conduct an area study before any project that involves ICTs is implemented. This enables the collection of socio-economic data and the identification of information requirements (education, family planning, legal matters, etc). As such, this study has portrayed that ICTs play an important role in accessing information in all spheres of life and that they clearly contribute to the enhancement of women's social lives. Secondly, the authors state that there is a need to always define objectives, establish a given project's methodology, and identify the project's beneficiaries. This ensures that the target audience, who in this case is the poor rural woman, is reached. Thirdly, it is essential to consider the legal implications of the setup. This establishes that all the necessary protocol has been observed. Fourthly, the information infrastructure in relation to the technology in question must be taken into consideration i.e. cultural traditions (oral), adapted tools (radio). In other words, it is important to ascertain how information flows in the community and the communication tools in use. In this way, the risks and threats in the use of ICTs will be avoided or minimized (Harris, 2004: 37). Fifthly, use existing infrastructure as an entry point into a community. (E.g. a school, a church, etc)

Needless to say, constraints facing developing countries are many and varied and could be said to hamper ICT development. They include the lack of purchasing power, inadequate training and human capacity, illiteracy, poor physical and information orientated infrastructures and inadequate access to capital and private investments (EC, 2000/200I:7). All these factors play an important role in the socio-economic fabric of a society. The World Bank (2002:1) points out three crucial elements required in efforts to combat poverty: opportunity, empowerment and security. According to this report, experiences in rural India indicate that ICTs can enhance poor people's opportunities by improving their access to markets and health care, empower them by expanding their use of government services, and increase security by widening access to micro-finance.

Although the radio is still commonly used by most rural women, it must be remembered that there is an urgent need to increase connectivity of the rural poor to the computer and the internet. This can be achieved through policies that increase connectivity and take into account, the constraints facing poor people (World Bank, 2002:2-3). According to the World Bank, competition between telecommunication companies can slash service costs and improve access to the technology in question. The World Bank argues that, since large telecom operators tend to limit their operations to high income urban areas, privatization should be opened up to allow small entrepreneurs to supply telecomm services to rural areas. Through "regulation and subsidies, private operators can be invited to bid to provide services in areas that are not commercially viable, in return for a subsidy financed from a Universal access fund".

Yet another point to consider, is the fact that interventions must be designed to reach the target beneficiaries, i.e. the rural poor woman (World Bank, 2002:4-5). According to the World Bank, "ICT projects that succeed in reducing poverty are generally run by organizations with a proven track record". Additionally, to be relevant to poor people, applications must take into account the local languages, be visually oriented, and use voice interfaces.

Lastly, there is the need for training, as learning is more effective through practice and innovative and interactive training (World Bank, 2002:5).

Given the where-it-all, the application of ICTs to development should always begin with a development strategy, superseded by an information plan, and then a plan for the information technology that will be capable of delivering the information resources required for the achievement of the development strategy (Harris, 2004:I).

\section{References}

Academy for Educational Development South Africa (undated). Women and IT in South Africa. [online]. Available: http:// projects.aed.org/techequity/SouthAfrica.htm Accessed 4.02.04.

Association for Progressive Communication (2005). Bangladesh mobile help-line for women .Available: http:i/www.apc.org/ english/news/index.shtml?x=1539037 Accessed 12.10.05. 
Adeya, C. (2002). ICTs and Poverty: a literature review. [online]. Available: http://www.google.co.za/

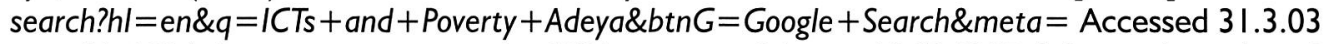

Basson, N. 1996. Passage to progress: the CSIR's journey of change 1945-1995. Johannesburg: Jonathan Ball Publishers.

Batchelor, S.; Scott, N. and Taylor, N. (2005). The contributions of ICTs to pro-poor growth.Online: Available at http:// www.oecd.org/dataoecd/ / 6//6/34662200.pdf Accessed on 02.05.06

Ballantyne, P., R. Labelle and S. Rudgard. (2000).Information and Knowledge Management: Challenges for Capacity Builders. (Policy Management Brief No. II). Maastricht: ECDPM. [Online]. Available: http://www.chs.ubc.ca/lprv/PDF/lprv0075.pdf Accessed on 02.05 .06

Bedi, A.1999. The role of information and communication technologies in economic development - a partial survey.

Bessette, G. (2004). Involving the community: a guide to participatory development communication. [online]. Available: $h t t p: / /$ www.worldcatlibraries.org/wcpa/ow/df5ec2e54677092da9afeb4da09e526.html Accessed 3 August 2005.

Bridges.org (200I). Spanning the Digital Divide: Understanding and tackling the issues. [online]. Available: http:// www.bridges.org/publications/65 Accessed on 02.05 .06

Community Empowerment (2004). ICT technologies and reproductive health [online]. Available: http:// www.communityempowernet.org/id22.html Accessed 14/03/06

Definition of Kwazulu-Natal Province [online]. Available: www.wordiq.com/definition/Kwazulu-Natal Province Accessed I I/I0/04

Development Report: Attacking Poverty (2000/200I). [online]. Available: http://www.worldbank.org/poverty/wdrpoverty/ index.htm. Accessed 5/11/05

European Commission (200I). Communication from the Commission to the Council and the European Parliament. Information and Communication Technologies in Development. The role of ICTs in EC Development Policy, Brussels, [online]. Available: http://europa.eu.int/eur-lex/en/com/cnc/200I/com200I_0770en0I.pdfAccessed 12.10.05.

Gay,L.R. (1996). Educational research: Competencies for analysis and application (5thEd.).Upper Saddle River, NJ:Merril/prentice Hall.

Grameen Telecomm (2005). [Online]. Available: www://southasia.oneworld.net/external/?url=http\%3A\%2F\%2Fwww.grameeninfo.org\%2Fgrameen\%2Fgtelecom\%2F 2005. Accessed 12.10.05

Harris, R. (2002). Rural development theories and ICTs. [online]. Available: http://www.bytesforall_readers/2002-August/ 00833. html Accessed 12 October 2003.

Harris, R. (2004). Information and Communication Technologies for poverty alleviation. UNDP/APDIP. [online]. Available: http:/ /eprimers.apdip.net/series/info-economy/poverty.pdf Accessed 6/1 1/05

Huyer, Sophia (1997). Supporting women's use of Information technologies for sustainable development. [online]. Available: http://www.wigsat.org/it/womenicts.html Accessed 10 June 2003.

Holcroft, E. (2005). SchoolNet South Africa. [online]. Available: http://www.idrc.ca/acacia/ev-7/274-20I-I-DO_TOPIC.html Accessed 30/01/06

Ilboudo J.P. (2003). The role and use of rural radio in Africa. In: The one to watch - radio, new ICTs and interactivity. Edited by Bruce Gerard. [online]. Available: ftp://ftp.fao.org/docrep/fao/006/y472/ e/y472 l e00.pdf Accessed 9/04/06.

Ikoja-Odongo, J.R. (2002). The study of information needs and uses of the informal sector of Uganda. Ph.D. thesis (unpublished), University of Zululand.

Ikoja-Odongo, R. (2002) Insights into the information needs of women in the informal sector of Uganda. South African Journal of Libraries \& Information Science Vol. 68, N.I, 39-52.

Information Technology Development Group (ITDG) (2005). Women's voices. [on-line]. Available: http://www.itdg.org/ ?id=womens_voices2 Accessed 6/I I/05.

Jiyane, Veli and Ocholla, Dennis N. (2004) An exploratory study of information availability and exploitation by the rural women of Melmoth, KwaZulu-Natal. South African Journal of Libraries and Information Science, Vol.70, N. I, I-8

Kenney, G.I. 1995. The missing link - information. Information Technology for development (6)33-38.

KwaZulu Natal (200I).The inside story on current affairs in Kwazulu Natal [online], available: http://www.profilekzn.co.za/ aboutKzn.html.

Maepa, M.E. (2003). Information and communication technology needs, use patterns and barriers in three tele-centres in Limpopo Province, South Africa. [online]. Available: http://www.idrc.ca/acacia/ev-56553-20I-I-DO_TOPIC.html Accessed 30/I/06

Marker, P., Mcnamara, K. \& Wallace, L. (2002). The significance of information and communication technologies for reducing poverty. [online]. Available: http://www.oecd.org/dac/ictcd/docs/matrixdocs/GBR_paperl.pdf. Accessed 31.03.06

Marcelle, G. M. (2003). Getting gender into African ICT Policy: a strategic view. [online].Available: http:// www.archive.idrc.ca/ books/focus/903/06-chp03.html Accessed January 72004.

Mooko, N. P. (2002). The use and awareness of women's groups as sources of information in three small villages in Botswana. South African Journal of Libraries \& Information Science, 68(2): $104-112$.

Moyo, L. M. 1996. Information technology strategies for Africa's survival in the twenty-first Century: IT all pervasive. Information technology for development. 7:17-27.

Mudhai, Fred O. (2004). Shs 444b. to be spent on phones upgrade by 20I5. [online]. http://www.nationaudio.com/News/ DailyNation/Supplements/horizon/ I50 I 2004/story/5012004 I.htm. Accessed January 152004.

Ngenge, G.A. (2003). Gender equity and new information and communication technologies. [online]. Available: http:// www.sdnp.undp.org/sdncmr/fawecam/ngenge.htm. Accessed: 12 August 2003.

Ngimwa, P., Ocholla, D. and Ojiambo, J. 1997. Media accessibility and utilization by Kenyan rural women. International Information and Library Review. 29: 45-66.

Organization for Economic Co-operation and Development (2004). The Economic impact of ICTs: measurement, evidence and implications. [online]. Available: $h t t p: / / w w w l . o e c d . o r g / p u b l i c a t i o n s / e-b o o k / 920405$ IE.PDF Accessed I4/03/06

Parkinson, S. (2005). Telecenters, Access and development: experience and lessons from Uganda and South Africa. [online]. Available: Accessed:28.01.06

SA Jnl Libs \& Info Sci 2006, 72(2) 
Rachel, S., Momo, M. (2005). Expanding the role of ICTs in Africa. [online]. Available: http://www.idrc.ca/acacia/ev-32970-20I-IDO TOPIC.html Accessed 28.01.06

Ranchōd, S. (200I). Information communication technologies for women's equality: access and empowerment issues - an Ngo perspective.[online], Available http://www.womenaction.org/gkii/sarital.html. Accessed 29.6.03.

Rathgeber, Eva M. (2000). Women, Men, and ICTs in Africa: Why Gender is an issue.[online]. Available: http:// crchive.idrc.ca/ books/focus/903/05-chp02.html. Accessed 8.01.03

Research ICT Africa. Towards an African e-Index (2004). [online]. Available: http://www.researchictafrica.net/images/upload/ Chapter09RSANEWfmPeter I.pdf Accessed 12.1I.05.

South African Statistics (200I). [online]. Available: http://www.statssa.gov.za/ Accessed 5. 10.04.

South Africa.Info (2006). South Africa's telecommunications infrastructure. [online]. Available: http://www.southafrica.info/ doing_business/economy/infrastructure/telecoms.htm Accessed 17/01/06

Snyman, M., Snyman, R. (2003). Getting information to disadvantaged rural communities: The centre approach. South African Journal of Libraries and Information Science, 2003, 69(2),95-107

United Nations Development Program, Evaluation Office. Information communications technology for development. Essentials: Syntheses of Lessons Learned No. 5 (September 200I). Available at: www.undp.org/eo/documents/essentials_5.PDF Accessed 28/02/06

Uthungulu Distict Municipality (2003). Development perspective. (Status Quo). Available online. http://www.uthungulu.org.za/ default.asp Accessed 5/10/04.

Uthungulu District Municipality (2004). Investment profile: brochure.

Uthungulu Distict Municipality (2004). Izindaba Ezimtoti. July/August 2004.

Umlalazi Integrated Development Plan (2002). [online]. Available: http://www.devplan.kzntl.gov.za/Municipal/IDPs/Umlalazi/ analysis IDP.pdf Accessed 10/12/05

Vodafone/DFID (2005). The impact of mobile phones. [online]. Available: http://www.vodafone.com/assets/files/en/ AIMP_09032005.pdf Accessed 9/04/06

Wagner, D.A. (2005). Literacy, Technological Literacy and the Digital Divide. [online].Available from: http: // www.techknowlogia'org/tkl_active_pages2/Current Articles/main.asp? File Type $=$ HTML\&Article ID $=116$.

World Development Report (1998/99). The power and reach of Knowledge. [online]. Available: http://www.worldbank.org/wdr/ wdr98/ch01.pdf Accessed I5/0I/06

World Bank (2002). Telecommunications and Information services for the poor. Towards a strategy for Universal Access http:// rru.worldbank.org/Documents/PapersLinks//2 10.pdf Accessed 18.03/06

World Bank. (2002) Prem notes. Using information and communications technology to reduce poverty in rural India. [online] Available: http://wwwl.worldbank.org/prem/PREMNotes/premnote70.pdf Accessed 5/I I/05 